Supporting Information

\title{
Waste Egg Tray and Toner-Derived Highly Efficient 3D Solar Evaporator for Freshwater Generation
}

Md. Nahian Al Subri Ivan ${ }^{1 a, b}$, Ahmed Mortuza Saleque ${ }^{1 a, b}$, Safayet Ahmed ${ }^{1 a, b}$, Ping Kwong Cheng ${ }^{1 a, b}$, Junpeng Qiao ${ }^{1 a, b}$, Tawsif Ibne Alam ${ }^{1 a}$, Yuen Hong Tsang ${ }^{1 a, b,{ }^{*}}$

1a.) Department of Applied Physics and Materials Research Center, The Hong Kong Polytechnic University, 99077, Hung Hom, Kowloon, Hong Kong

1b.) Shenzhen Research Institute, The Hong Kong Polytechnic University, 518057 Shenzhen, Guangdong, People's Republic of China

*.) Corresponding author: yuen.tsang@polyu.edu.hk 


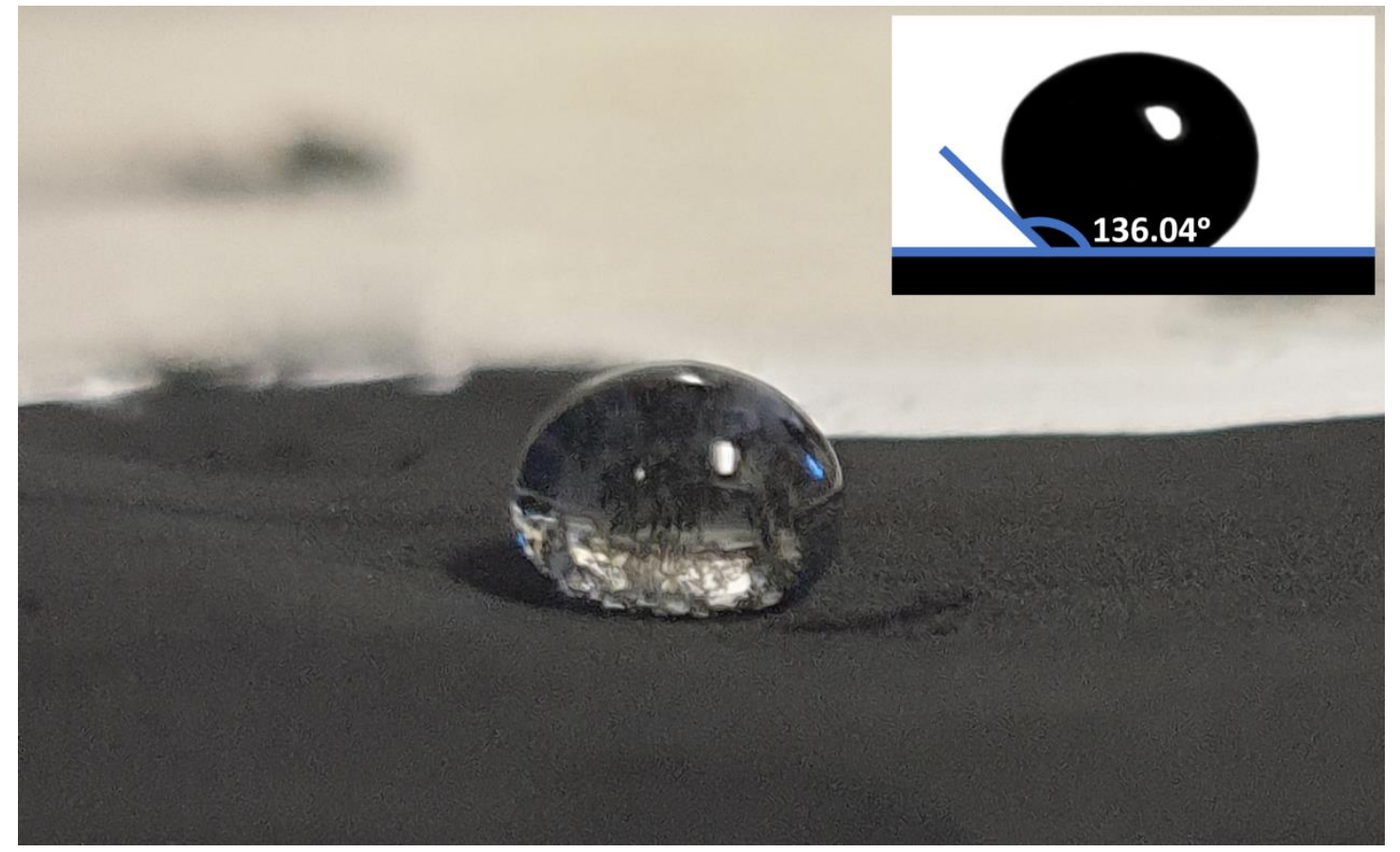

Figure S1: Water drop on dry toner, measured contact angle (inset) 

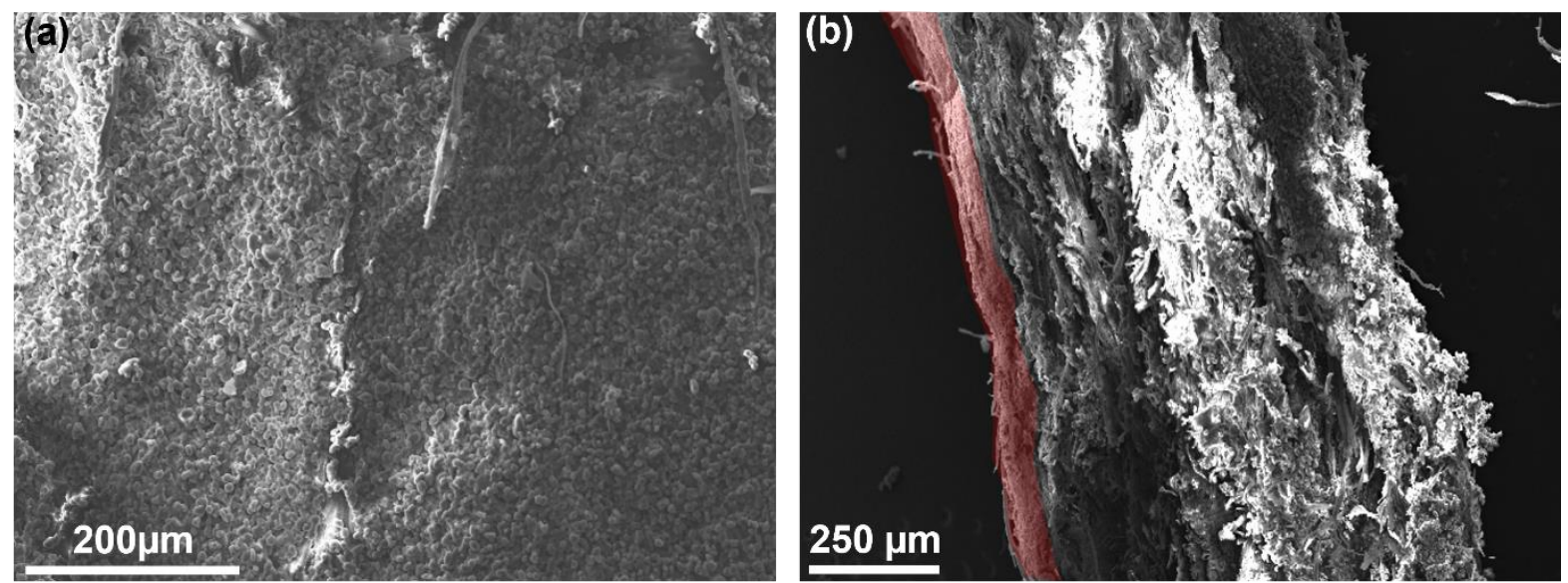

(c)

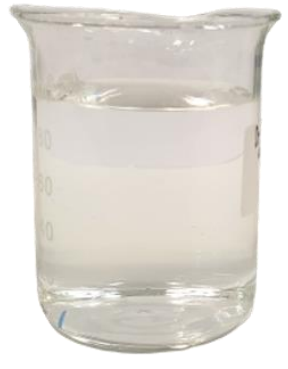

Clear water

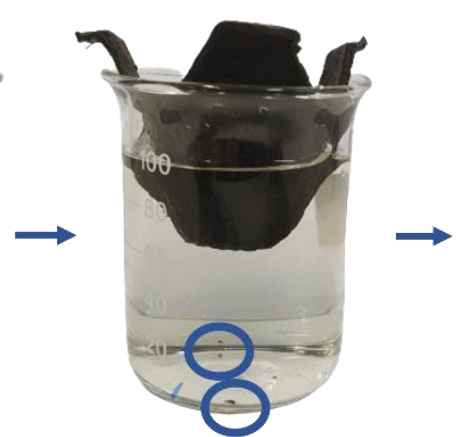

Contamination within 20 seconds
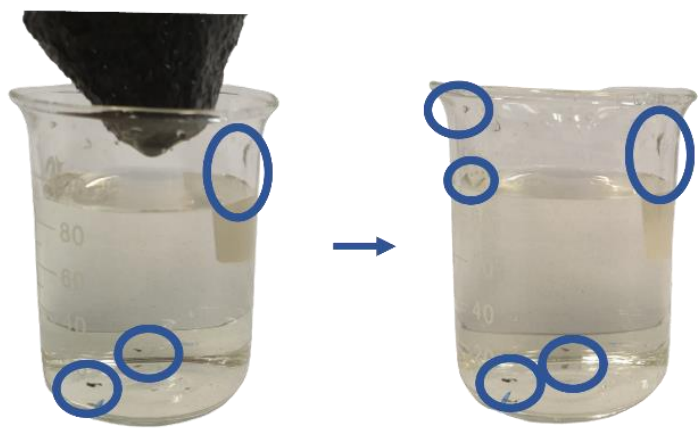

Contamination by toner after 5 minutes
Toner particles at the contact point of beaker and egg tray

Figure S2: SEM image of coated egg tray (heat treatment temperature $85^{\circ} \mathrm{C}$ ) and its disadvantage. a) SEM image of the surface of the heat treated $\left(85^{\circ} \mathrm{C}\right)$ egg tray. b) Cross section of the heat treated $\left(85^{\circ} \mathrm{C}\right)$ egg tray showing very little penetration of toner to paper (red area). c) Contamination by the low heat treated coated egg tray. 

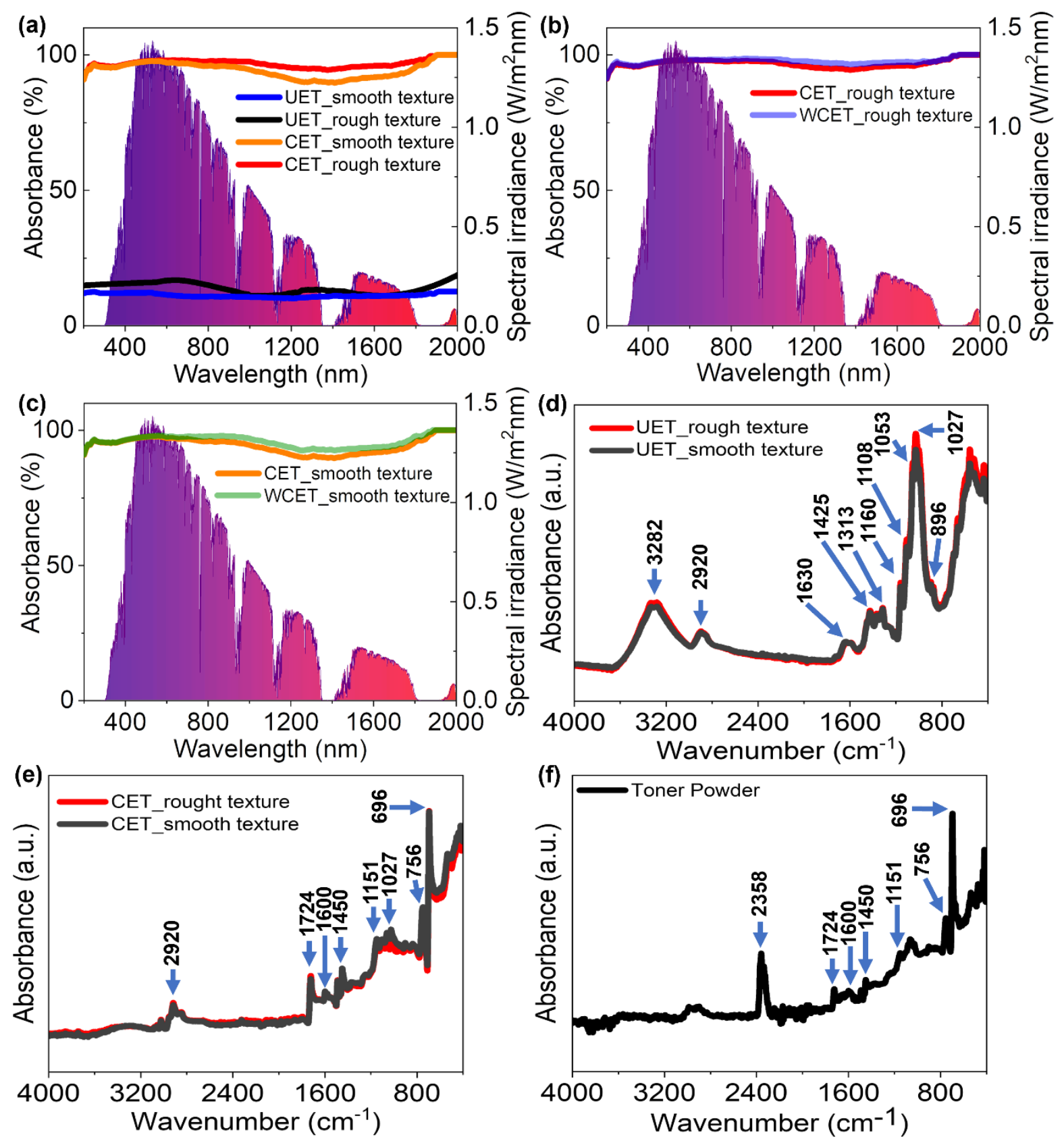

Figure S3: Characterization of CET and UET for both rough texture and smooth texture. a) The UV-Vis-NIR absorption spectrum of CET and UET for both rough and smooth texture. b) The UV-Vis-NIR absorption spectrum of CET rough texture (dry sample) and WCET rough texture (wet sample). c) The UV-Vis-NIR absorption spectrum of CET smooth texture (dry sample) and WCET smooth texture (wet sample). FTIR-ATR absorption spectrum of d) UET for both rough and smooth texture. e) CET for both rough and smooth texture. f) Dry toner powder. 
Table ST1: Characteristic absorption bands of UET (uncoated surface), Toner and CET (coated surface)

\begin{tabular}{|c|c|c|c|}
\hline & $\begin{array}{l}\text { Absorption } \\
\left(\mathrm{cm}^{-1}\right)\end{array}$ & Assignment & Reference \\
\hline \multirow{10}{*}{ UET } & 3282 & Vibration of $-\mathrm{OH}$ & 1,2 \\
\hline & 2920 & $\mathrm{C}-\mathrm{H}$ stretching (asymmetric) & $3-5$ \\
\hline & 1630 & $\mathrm{OH}$ in $\mathrm{H}_{2} \mathrm{O}$ bending (moisture) & 5 \\
\hline & 1425 & $\mathrm{C}-\mathrm{H}$ bending vibration of $\mathrm{CH}_{2}$ & 6 \\
\hline & 1313 & $\mathrm{O}-\mathrm{H}$ bending vibration & 7 \\
\hline & 1160 & C-O-C stretching & 8 \\
\hline & 1108 & Aromatic $\mathrm{C}-\mathrm{H}$ in plane deformation & 8 \\
\hline & 1053 & $\mathrm{C}-\mathrm{OH}$ stretching vibration, $\mathrm{C}-\mathrm{O}$ deformation & 8 \\
\hline & 1027 & Presence of cellulose & 9 \\
\hline & 896 & C-O-C stretching & 8 \\
\hline \multirow{6}{*}{ Toner } & 2358 & $\begin{array}{l}\text { Presence of } \mathrm{CO}_{2} \text { in sample (could be due to } \\
\text { presence in background or absorption of } \mathrm{CO}_{2} \\
\text { by sample) }\end{array}$ & 10 \\
\hline & 1724 & $\mathrm{C}=\mathrm{O}$ groups & 11,12 \\
\hline & 1600 & $\mathrm{C}=\mathrm{O}$ stretching vibration in ketones & 13 \\
\hline & 1450 & $\mathrm{CH}_{3}$ vibartion & 14 \\
\hline & 1151 & Bending vibration of $\mathrm{C}-\mathrm{H}$ of benzene ring & 15 \\
\hline & $\begin{array}{l}756 \\
696 \\
\end{array}$ & $\begin{array}{l}\text { Bending vibration of monosubstituted } \\
\text { benzene ring }\end{array}$ & 15 \\
\hline \multirow{7}{*}{ CET } & 2920 & C-H stretching (asymmetric) & $3-5$ \\
\hline & 1724 & $\mathrm{C}=\mathrm{O}$ groups & 11,12 \\
\hline & 1600 & $\mathrm{C}=\mathrm{O}$ stretching vibration in ketones & 13 \\
\hline & 1450 & $\mathrm{CH}_{3}$ vibartion & 14 \\
\hline & 1151 & Bending vibration of $\mathrm{C}-\mathrm{H}$ of benzene ring & 15 \\
\hline & 1027 & Presence of cellulose & [9] \\
\hline & $\begin{array}{l}756 \\
696\end{array}$ & $\begin{array}{l}\text { Bending vibration of monosubstituted } \\
\text { benzene ring }\end{array}$ & 2 \\
\hline
\end{tabular}


(a)

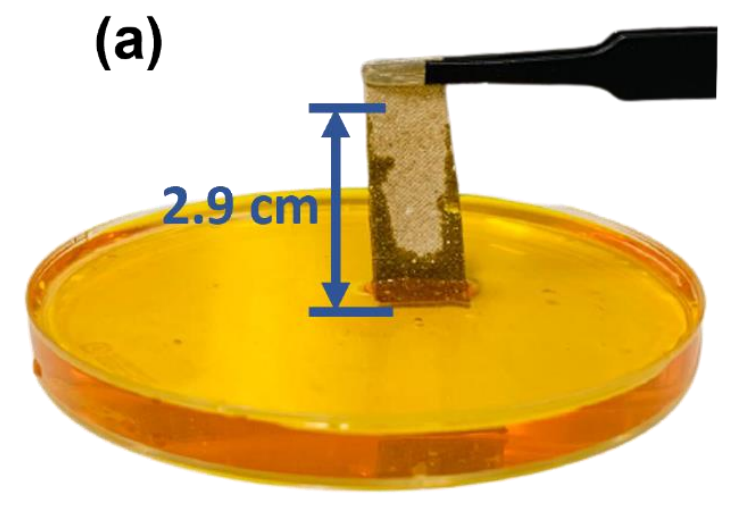

(c)

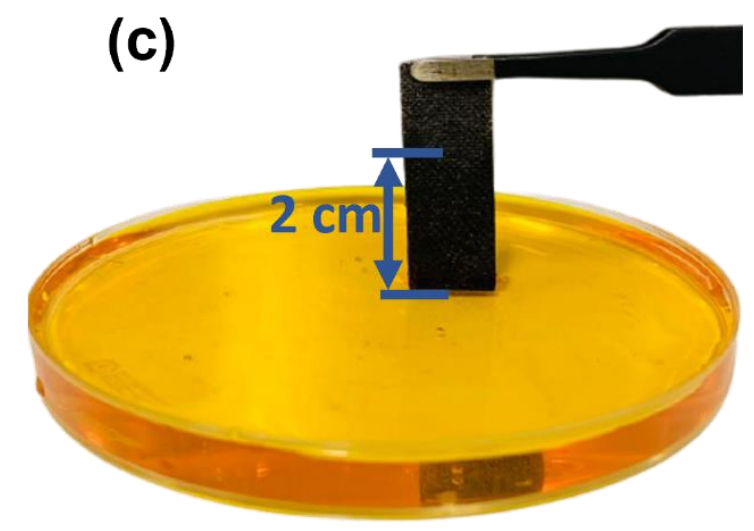

(b)

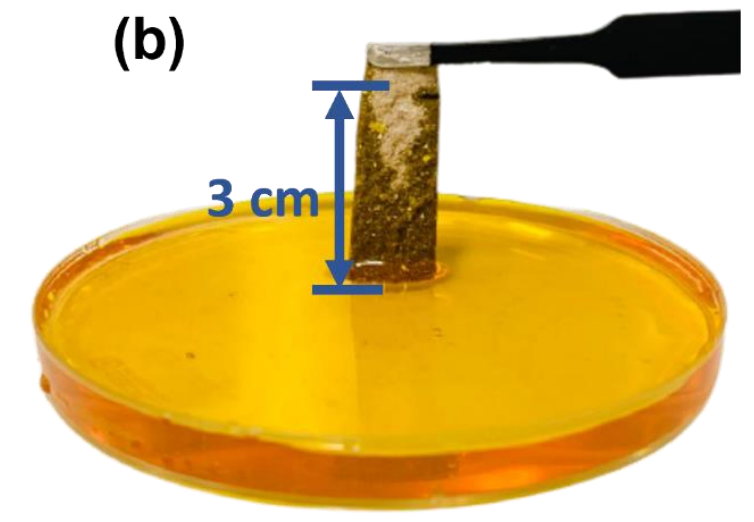

(d)

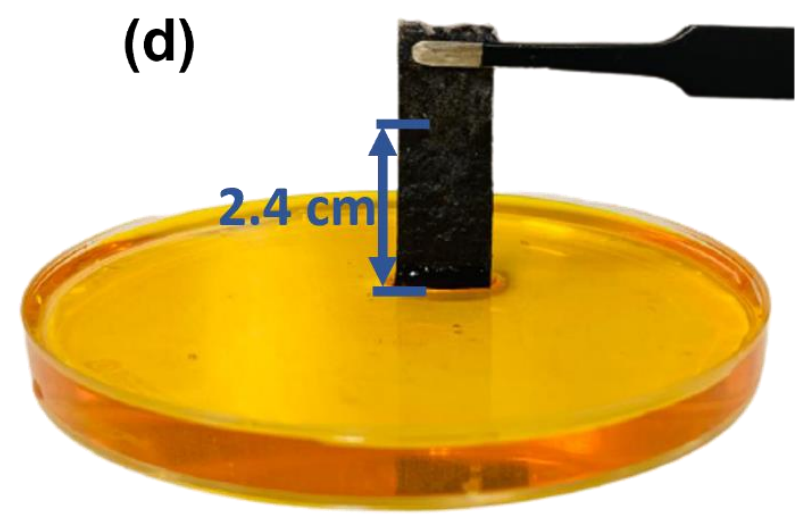

(e)

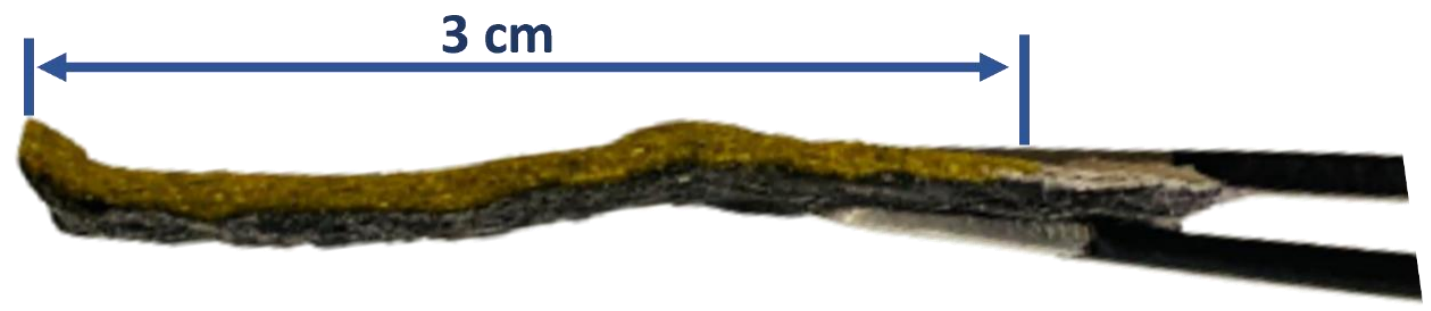

Figure S4: Water uptake experiment. Water uptake by a) UET smooth textured surface. b) UET rough textured surface. c) CET smooth textured surface. d) CET rough textured surface. e) Enhanced picture of CET rough texture surface showing water uptake by the other side of the evaporator. 

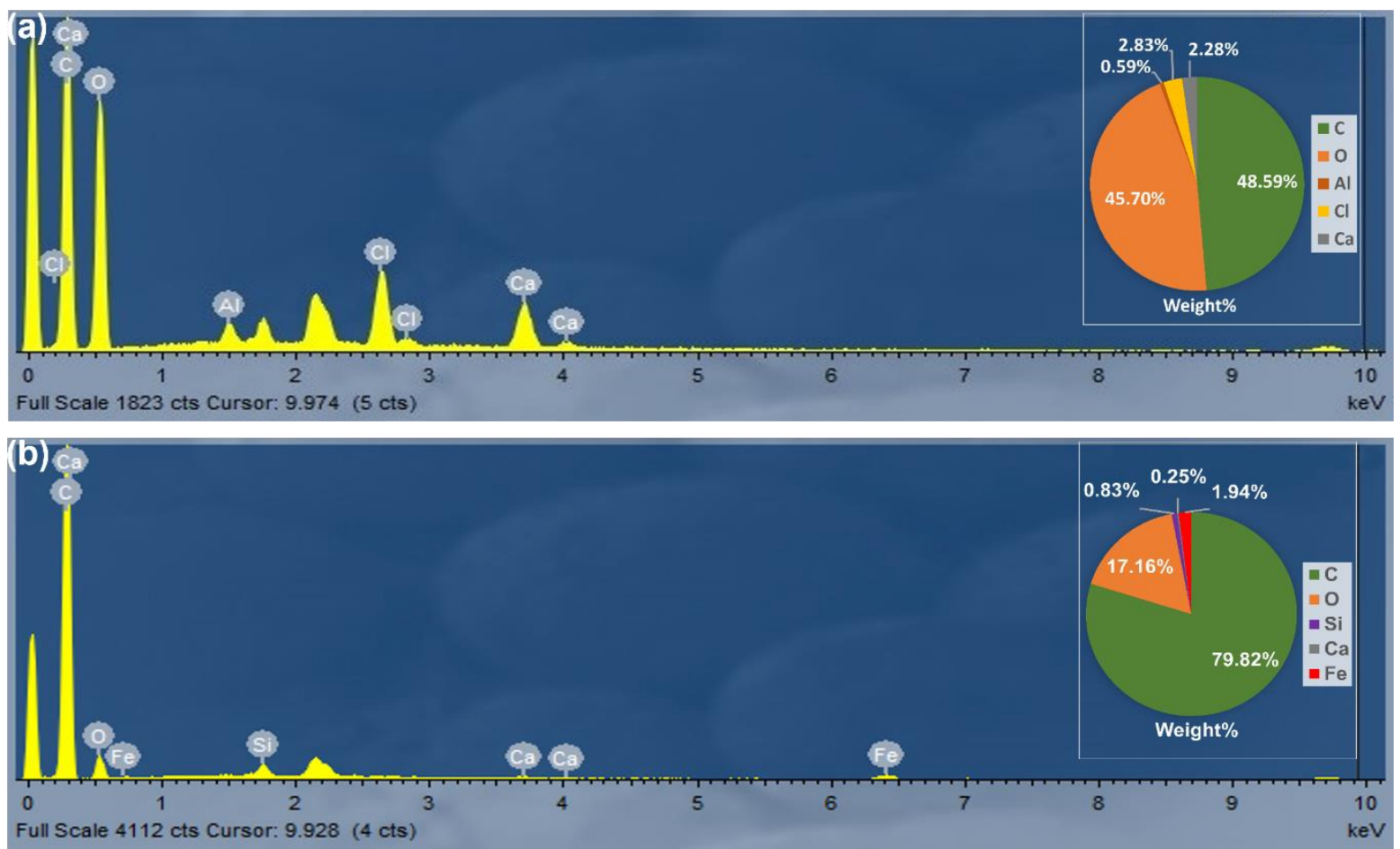

Figure S5: EDX Spectrum. a) EDX spectrum of UET, weight\% of each element is presented in a pie chart (inset). b) EDS spectra of CET weight\% of each element is presented in a pie chart (inset). 
(a)
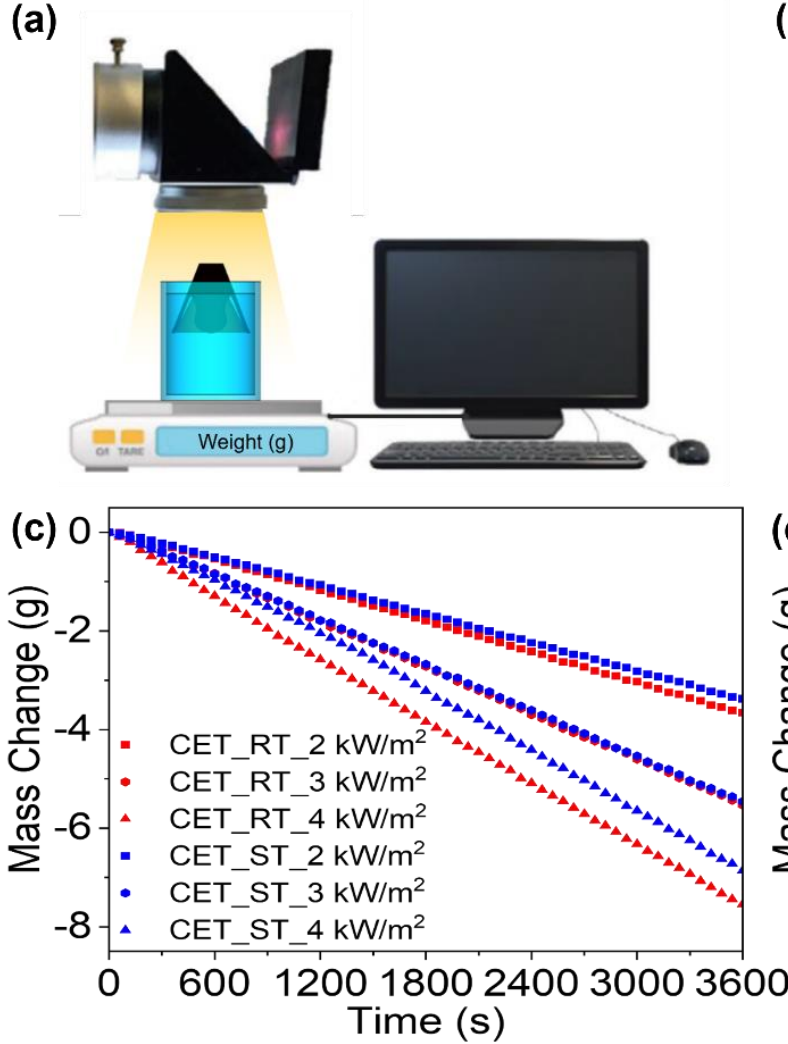

(b)

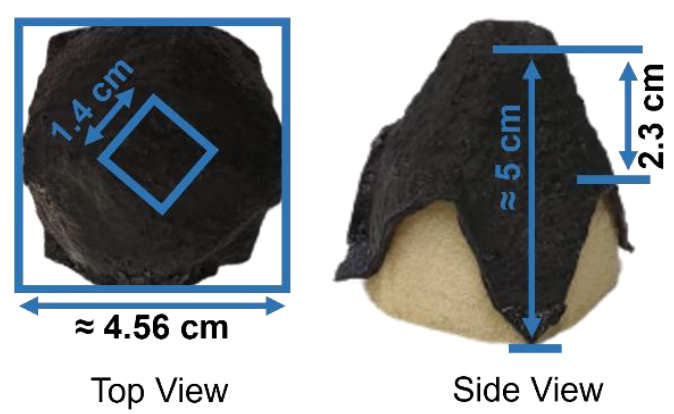

Top View

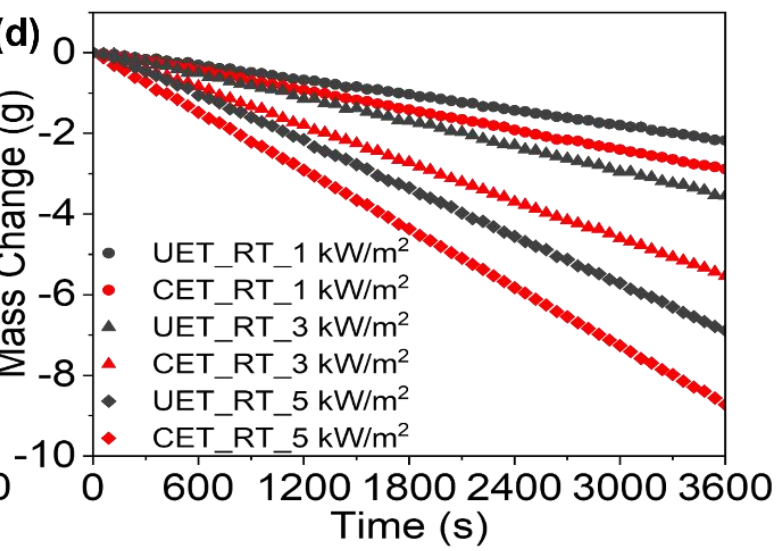

Figure S6: Experimental setup and observations. a) The schematic diagram of the experimental setup. b) Dimension of the 3D evaporator. c) The mass change rate of water due to the presence of CET (both rough and smooth texture) under different solar irradiation. d) The mass change rate of water due to the presence of rough textured (both UET and CET) evaporator under different solar irradiation. 


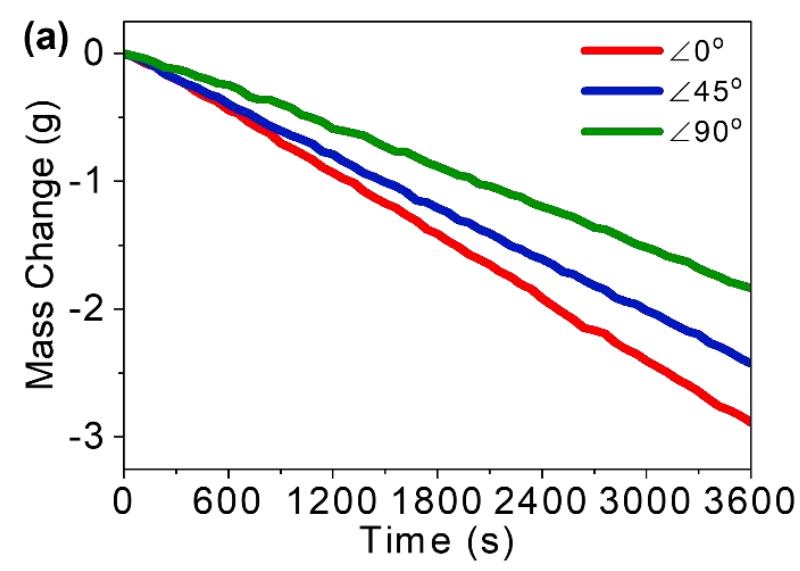

(b)
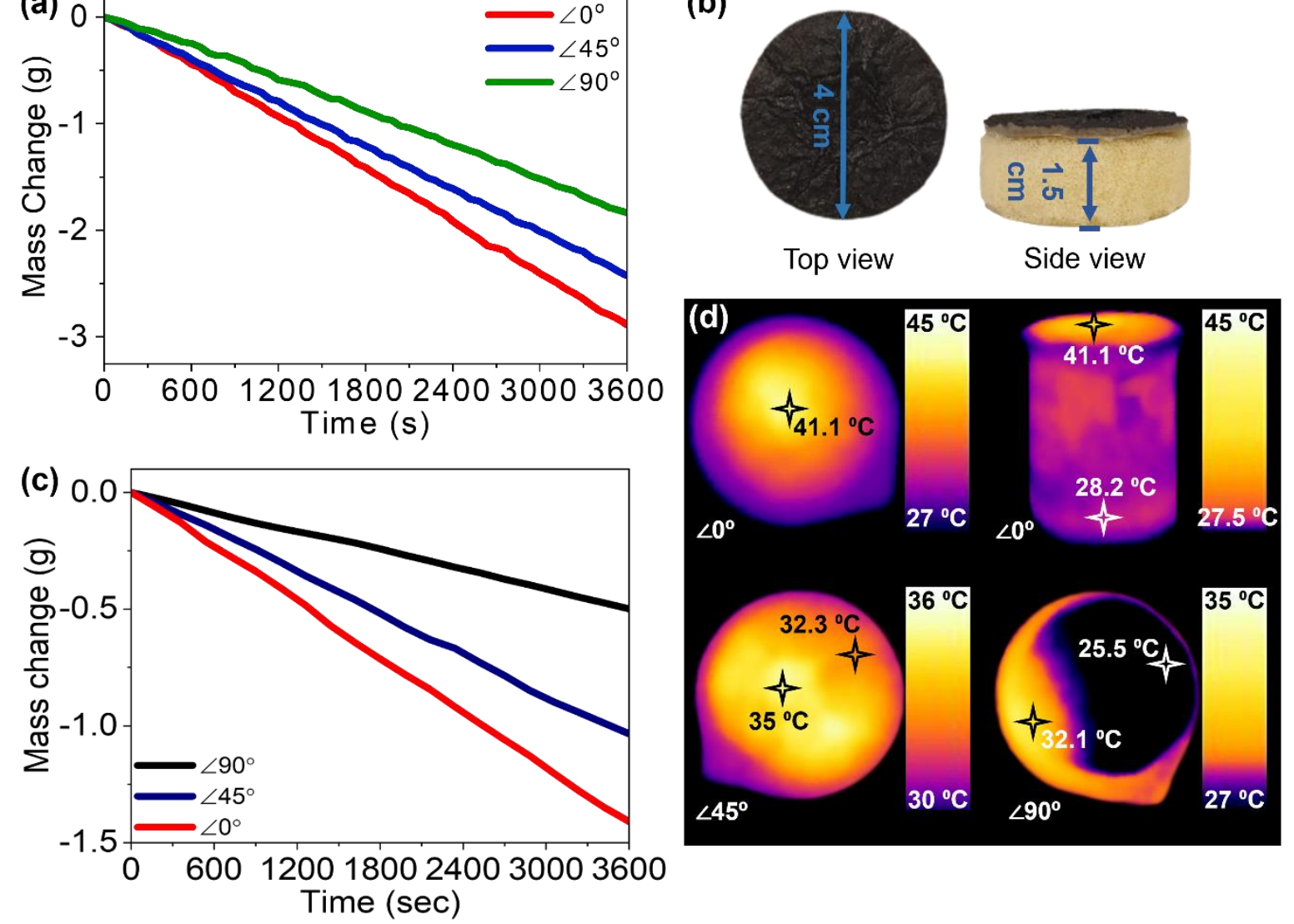

Figure S7: Experiment with 2D structure, observations and comparison. a) Mass change rate of water in the presence of 3D (CET rough texture) structure at different light incident angle. b) Dimension of the 2D evaporator. c) Mass change rate of water in the presence of 2D (CET rough texture) structure at different light incident angle. d) Thermal image of 2D evaporator after one hour of evaporation at different light incident angle. 
(a)

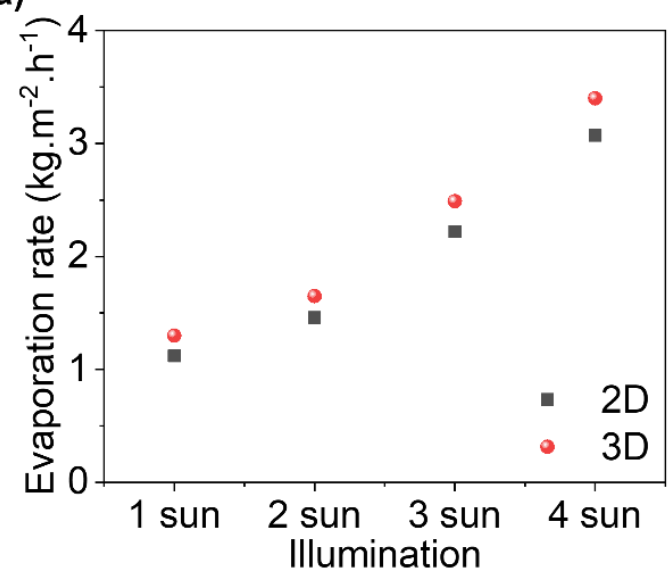

(b)

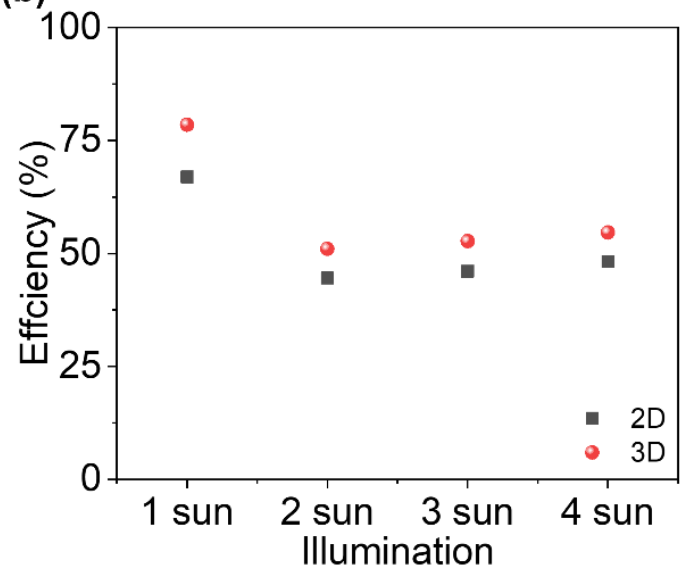

Figure S8: Comparison between 2D and 3D structure of $\mathrm{CET}_{\text {rough }}$ texture evaporator. a) Evaporation rate of $2 \mathrm{D}$ and $3 \mathrm{D}$ structure. b) Efficiency of $2 \mathrm{D}$ and $3 \mathrm{D}$ structure 

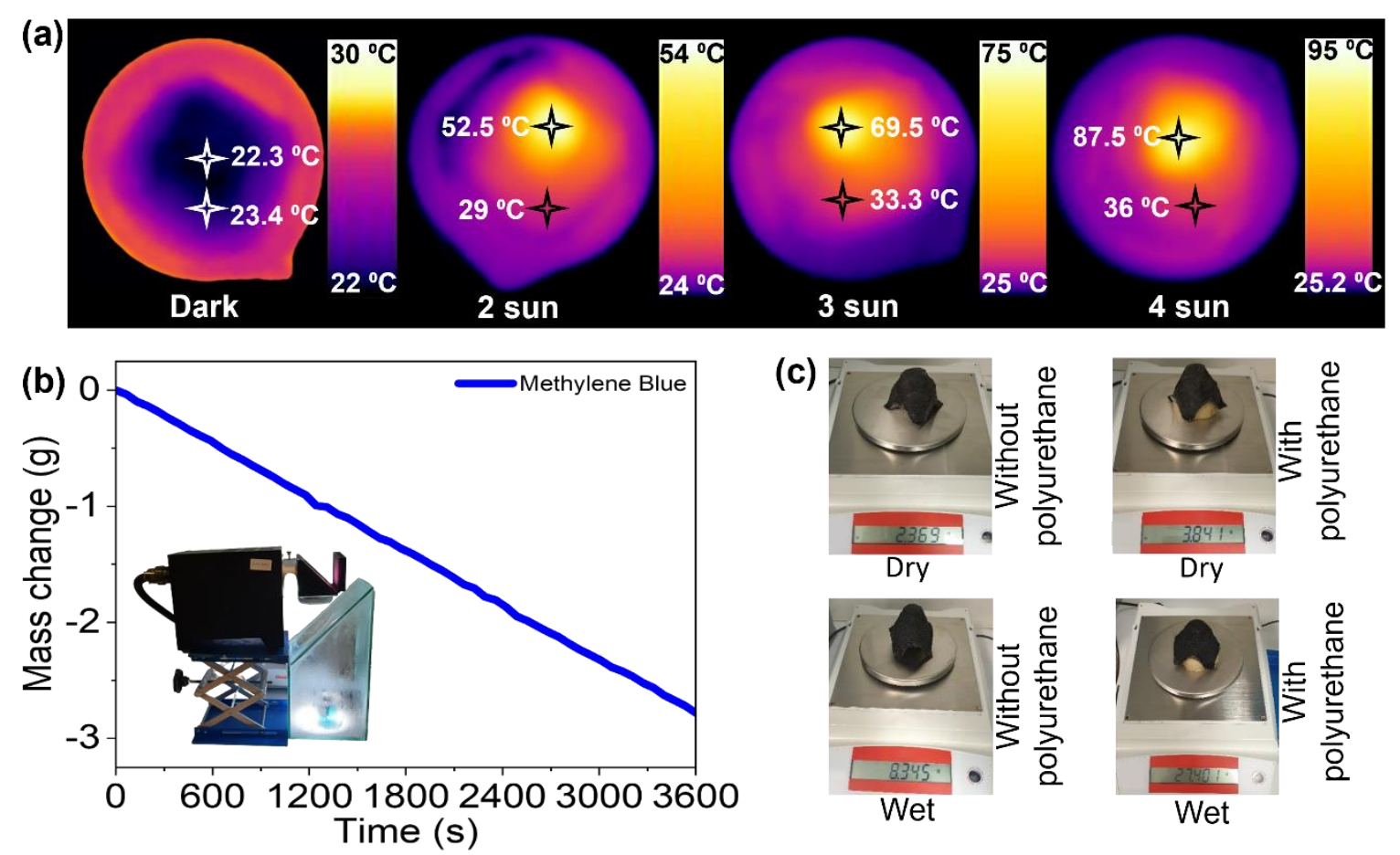

(c)

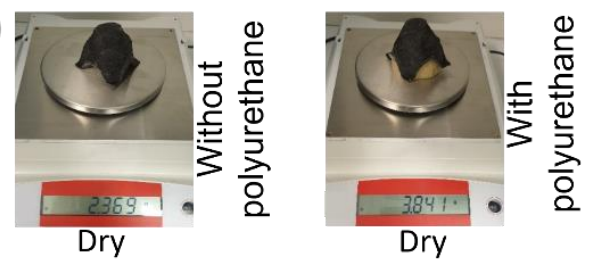

(d)
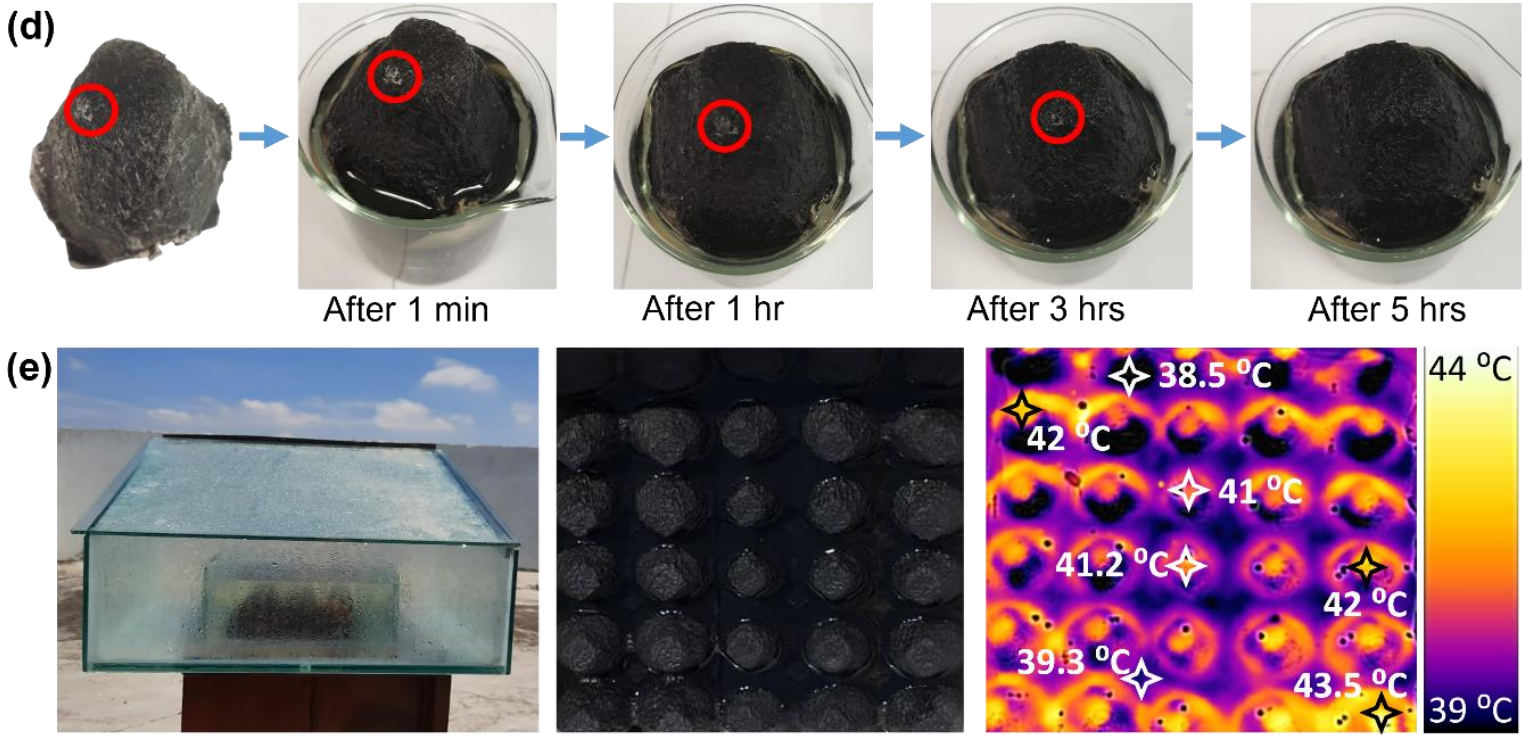

Figure S9: Experiment and observations. a) Thermal image of 3D evaporator during dark evaporation and after one hour of evaporation under 2 sun, 3 sun and 4 sun illumination. b) Mass change rate of Methylene Blue under 1 sun illumination with experimental setup (inset). c) weight of dry and wet evaporator. d) observation of dissolving accumulated salt in $10 \mathrm{wt} \%$ brine water. e) experimental setup for outdoor experiment and the thermal image of the evaporator after 1 hour of evaporation. 

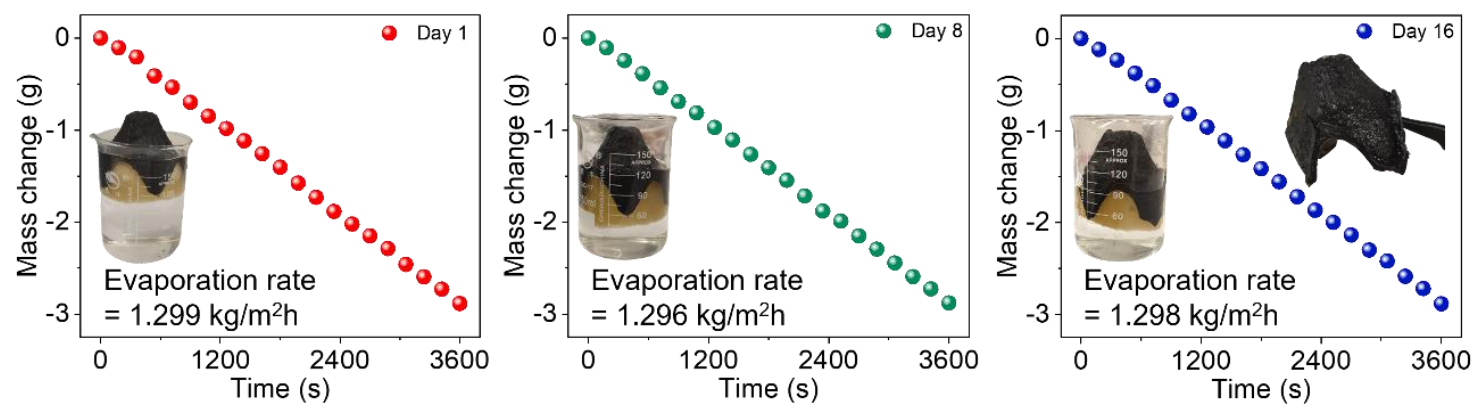

Figure S10: Checking the performance and condition of the CETrough texture evaporator in long run.

\section{Supporting note 1:}

The evaporation rate, $m_{e}$ can be calculated by following equation:

$m_{e}=\frac{m_{h}}{A}$

Where, $m_{h}$ is mass loss of water per hour due to evaporation and $A$ is the area of evaporation surface.

$\eta_{s e}=\frac{m_{l}\left(H_{L V}+Q\right)}{E_{\text {in }}}$

$H_{L V}=1.91846 * 10^{6} *\left[T_{e} / T_{e}-33.91\right]^{2}$

$Q=c *\left(T_{e}-T_{w}\right)$

Where, $m_{l}=$ net evaporation rate $\left(\mathrm{kg} / \mathrm{m}^{2}\right)$,

$m_{l}=m_{e}-m_{d}$

$m_{d}=$ dark evaporation rate

$E_{\text {in }}=$ energy input of the incident light $\left(\mathrm{kJ} / \mathrm{m}^{2} \mathrm{~h}\right)$,

$H_{L V}=$ is the latent heat required for vaporization of water $(\mathrm{J} / \mathrm{kg})$, 
$T_{e}=$ is the average temperature of the solar evaporation surface,

$Q=$ is the required heat for increasing the temperature of water,

$c=$ is the specific heat of water $(4.2 \mathrm{~J} / \mathrm{gK})$,

$T_{w}=$ initial temperature of top surface

For 3D evaporator (CET rough texture) under 1 sun illumination, $T_{e}=305.253 \mathrm{~K}, T_{w}=$ $295.5 \mathrm{~K}, m_{e}=1.3 \mathrm{~kg} / \mathrm{m}^{2} \mathrm{~h}, m_{d}=0.136 \mathrm{~kg} / \mathrm{m}^{2} \mathrm{~h}$, Hence, from the above-mentioned equation the efficiency becomes $78.5 \%$.

For 3D evaporator (CET smooth texture) under 1 sun illumination, $T_{e}=304.16 \mathrm{~K}, T_{w}=$ $295.5 \mathrm{~K}, m_{e}=1.201 \mathrm{~kg} / \mathrm{m}^{2} \mathrm{~h}, m_{d}=0.124 \mathrm{~kg} / \mathrm{m}^{2} \mathrm{~h}$, Hence, from the above-mentioned equation the efficiency becomes $72.7 \%$.

\section{Supporting note 2:}

The standard deviation of the evaporation rate of tap water and sea water were calculated using the following equation:

$\sigma=\sqrt{\frac{\sum\left(x_{i}-\mu\right)^{2}}{N}}$

Here,

$\sigma=$ The population standard deviation

$x_{i}=$ Each value from the total population

$\mu=$ Mean of the population

$\mathrm{N}=$ Size of the population 


\section{Supporting note 3}

Mass water absorption

$a_{m}(\%)=\frac{m_{w}-m_{d}}{m_{d}} \times 100$

Here

$m_{w}=$ mass of wet evaporator after 1 hour of evaporation experiment under 1 sun

$m_{d}=$ mass of the dry evaporator

Masses of wet evaporator with and without polyurethane structure are $27.401 \mathrm{~g}$ and $8.345 \mathrm{~g}$

Masses of dry evaporator with and without polyurethane structure are $3.841 \mathrm{~g}$ and $2.369 \mathrm{~g}$

The mass water absorption of the evaporator with polyurethane structure is $613.38 \%$ and without polyurethane structure is $252.26 \%$

\section{Supporting note 4}

Heat loss by conduction:

Energy loss due to heat conduction from evaporator to water can be calculated using temperature gradient and Fourier's law

$$
q_{\text {cond }}=k A \frac{\Delta \mathrm{T}}{L}
$$

Where, $k$ is thermal conductivity of water $=0.617 \mathrm{~W} / \mathrm{m} . \mathrm{K}$ and $\frac{\Delta \mathrm{T}}{L}$ is the temperature gradient. So percentage of conductive heat loss can be calculated using following equation

$\eta_{\text {cond }}=\frac{k A \frac{\Delta T}{L}}{A q_{s}}=\frac{k \frac{\Delta \mathrm{T}}{L}}{q_{s}}$ 
Considering the temperature of the bottom surface $\left(24.1^{\circ} \mathrm{C}\right)$ of the evaporator and temperature of water $2 \mathrm{~cm}$ below of the evaporator $\left(23.3^{\circ} \mathrm{C}\right)$ the percentage conductive heat loss is $2.47 \%$.

Heat loss by convection:

From Newton's law of cooling the convective heat transfer loss can be written as

$q_{\text {conv }}=A h\left(T_{\text {ase }}-T_{a}\right)$

Here,

$A=$ effective surface area (area above water) of the evaporation

$h=$ Convective heat transfer coefficient of air in natural convection $=5 \mathrm{~W} / \mathrm{m}^{2} . \mathrm{K}$

$T_{a s e}=$ Average temperature of the effective surface of the evaporator.

$T_{a}=$ Ambient temperature

The ratio of the energy losses caused by the convective heat transfer can be calculated by the following equation.

$$
\eta_{c o n v}=\frac{A h\left(T_{a s e}-T_{a}\right)}{A q_{s}}=\frac{h\left(T_{a s e}-T_{a}\right)}{q_{s}}
$$

$q_{s}=$ Incident solar flux per unit area

For the $3 d$ structure the temperature of the evaporator is different at different solar absorbing area. Due to the low thermal conductivity of the evaporator the temperature of the top flat surface (closer to light source) is $44.6^{\circ} \mathrm{C}$ and the temperature of the surface above the water is $26.5^{\circ} \mathrm{C}$. hence considering average temperature of $32.2253^{\circ} \mathrm{C}$ and ambient temperature of $25^{\circ} \mathrm{C}$ the average percentage convection heat loss can be calculated as $3.61 \%$.

Heat loss by radiation: 
The energy loss due to thermal radiation from the surface of the evaporator can be calculated using Stefan-Boltzmann's equation:

$q_{\text {rad }}=\varepsilon A \sigma\left(T_{a s e}^{4}-T_{a}^{4}\right)$

Where,

$\varepsilon=$ emissivity of the effective surface of the evaporator, which can be calculated using following equations:

$\alpha=1-R(\lambda)-T(\lambda)=\frac{\int_{250}^{2500} I(\lambda)(1-R(\lambda)) d \lambda}{\int_{200}^{2000} I(\lambda) d \lambda}$

$\varepsilon=1-\alpha=\frac{\int R(\lambda) P_{\operatorname{Sun}}(\lambda) d \lambda}{\int P_{\operatorname{Sun}}(\lambda) d \lambda}$

Here, $\alpha=$ solar absorptance, $R(\lambda)$ is the reflectivity function of the sample at different wavelength, $I(\lambda)$ is the light intensity function of the solar spectrum at different wavelength and $T(\lambda)$ is the transmitivity function of the sample at different wavelength. For non-transparent sample $T(\lambda)$ can be considered 0 .

The emissivity of the toner loaded solar absorbing surface of the evaporator was found to be $\approx 0.94$ which is nearly equal to the emissivity of dull black paper ${ }^{16}$. $\sigma=$ Stefan-Boltzmann constant $=5.67 \times 10^{-8} \mathrm{~W} / \mathrm{m}^{2} \mathrm{~K}^{4}$

The radiation loss rate can be calculated by:

$\eta_{\text {rad }}=\frac{\varepsilon A \sigma\left(T_{a s e}^{4}-T_{a}^{4}\right)}{A q_{s}}=\frac{\varepsilon \sigma\left(T_{a s e}^{4}-T_{a}^{4}\right)}{q_{s}}$

the average percentage radiative heat loss can be calculated as $4.23 \%$ 


\section{Supporting note 5:}

\section{Energy loss and gain in the hot and cold region of evaporating surface}

Energy loss $\left(Q_{\text {loss }}\right)$ to environment from hot surface and energy gain $\left(Q_{\text {gain }}\right)$ from environment at cold surface can be calculated by following equations:

$Q_{\text {loss }}=-A_{h} h\left(T_{h}-T_{a}\right)-\varepsilon \sigma A_{h}\left(T_{h}^{4}-T_{a}^{4}\right)$

$Q_{\text {gain }}=-A_{c} h\left(T_{c}-T_{a}\right)-\varepsilon \sigma A_{c}\left(T_{c}^{4}-T_{a}^{4}\right)$

Where,

$A_{h}=$ Area of the hot region of the evaporating surface

$A_{c}=$ Area of the cold region of the evaporating surface

$T_{h}=$ Average temperature of the hot region of the evaporating surface.

$T_{c}=$ Average temperature of the cold region of the evaporating surface.

For $\angle 90^{\circ}$ light incident angle, $A_{h}=0.00111 \mathrm{~m}^{2}, A_{c}=0.00111 \mathrm{~m}^{2}, T_{h}=304.3 \mathrm{~K}, T_{c}=$ $295 \mathrm{~K}$. Using equation 16 and $17, Q_{\text {loss }}=0.076 \mathrm{~W}, Q_{\text {gain }}=0.035 \mathrm{~W}$

Similarly, for $\angle 45^{\circ}$ light incident angle, $A_{h}=0.00148 \mathrm{~m}^{2}, A_{c}=0.00074 \mathrm{~m}^{2}, T_{h}=305.13$ $\mathrm{K}, T_{c}=296 \mathrm{~K} \cdot Q_{\text {loss }}=0.114 \mathrm{~W}, Q_{\text {gain }}=0.016 \mathrm{~W}$

\section{Supporting Note 6:}

The thermal conductivity of the dry toner coated egg tray can be calculated from the DSC curve (figure S11) by using the Fourier's law ${ }^{17}$ :

$Q=\lambda \Delta T \frac{A}{L}$

Here, 
$Q$ is the heat transfer rate, $\lambda$ is the average thermal conductivity, $A$ is the crosssectional area of the sample and $\frac{\Delta T}{L}$ is the temperature gradient.

Hence

$\lambda=\frac{Q L}{A \Delta T}$

The heat required to maintain the temperature gradient can be found from the difference between DSC readings at two different temperatures $\left(T_{1}\right.$ and $\left.T_{2}\right)$.

$Q=H_{2}-H_{1}$

A small sample was taken from the coated egg tray for DSC analysis. The Sample of $10 \mathrm{~mm}^{2}$ cross sectional area and $1.12 \mathrm{~mm}$ width was heated inside an aluminium crucible under the presence of a reference crucible from $30^{\circ} \mathrm{C}$ to $100{ }^{\circ} \mathrm{C}$ at $10{ }^{\circ} \mathrm{C} / \mathrm{min}$ rate in (Mettler Toledo DSC3. The $\mathrm{N}_{2}$ gas flow rate was selected $50 \mathrm{~mL} / \mathrm{min}$. Using equation (15) the average thermal conductivity near room temperature was found to be $0.21 \mathrm{~W} / \mathrm{m} . \mathrm{K}$ which is lower than thermal conductivity of water $\left(0.6176 \mathrm{~W} / \mathrm{m} . \mathrm{k}{ }^{18}\right)$ and higher than polyurethane $\left(0.02-0.029 \mathrm{~W} / \mathrm{mK}^{19}\right)$.

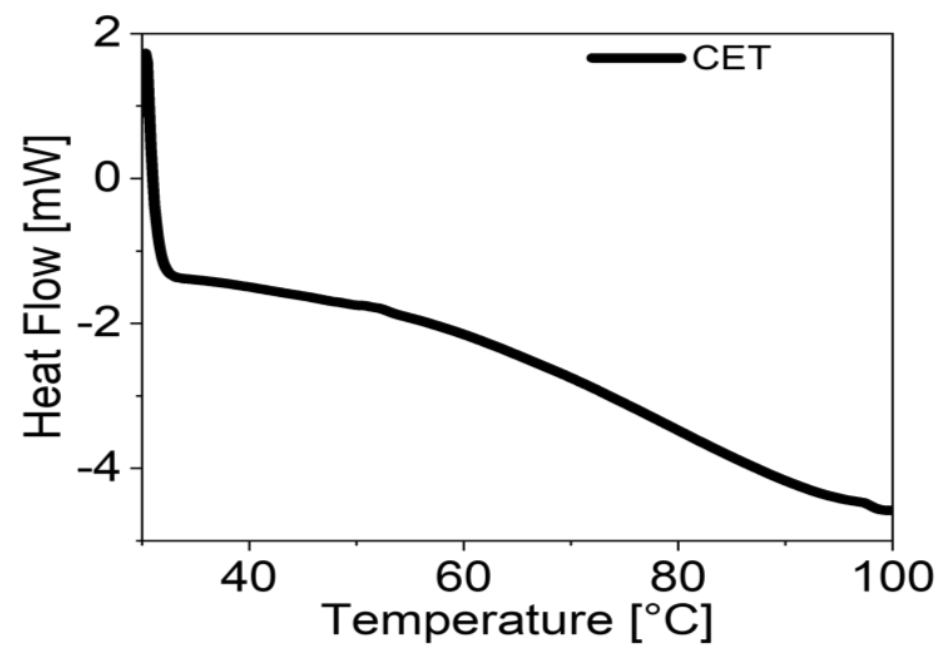

Figure S11: DSC curve of coated egg tray 
Table ST2: The efficiency, evaporation rate and processing temperature of biomass, and waste based Solar Evaporator.

\begin{tabular}{|c|c|c|c|c|}
\hline Evaporator & $\begin{array}{c}\text { Evaporation } \\
\text { rate } \\
\left(\mathrm{kg} / \mathrm{m}^{2} \mathrm{~h}\right)\end{array}$ & $\begin{array}{c}\text { Efficiency } \\
\text { (\%) } \\
\text { (under } 1 \\
\text { sun) }\end{array}$ & $\begin{array}{l}\text { Processing } \\
\text { Temperature }\end{array}$ & Ref. \\
\hline Carbonized Mushroom & 1.475 & 78 & $\begin{array}{l}500^{\circ} \mathrm{C} \text { in argon for } 12 \\
\text { hours }\end{array}$ & 20 \\
\hline $\begin{array}{l}\text { Carbonized coffee } \\
\text { ground }\end{array}$ & 1.05 & 71.7 & $\begin{array}{l}1000^{\circ} \mathrm{C} \text { for } 1 \text { hour } \\
\text { under nitrogen } \\
\text { atmosphere }\end{array}$ & 21 \\
\hline $\begin{array}{l}\text { Carbonized moldy } \\
\text { bread }\end{array}$ & 0.92 & 71.4 & & 22 \\
\hline Carbonized loofah & 1.42 & 89.9 & $\begin{array}{l}500^{\circ} \mathrm{C} \text { for } 30 \mathrm{sec} \text { in } \\
\text { hotplate }\end{array}$ & 23 \\
\hline Carbonized Loofah & 1.36 & 83.7 & $\begin{array}{l}500^{\circ} \mathrm{C}, 600^{\circ} \mathrm{C}, 700 \\
{ }^{\circ} \mathrm{C}, 800^{\circ} \mathrm{C} \text { for } 2 \text { hours }\end{array}$ & 24 \\
\hline $\begin{array}{l}\text { Carbonized Pencils } \\
\text { shaving }\end{array}$ & 1.2 & 82.2 & $900^{\circ} \mathrm{C}$ for 5 hours & 25 \\
\hline $\begin{array}{l}\text { Carbonised lotus } \\
\text { seedpod }\end{array}$ & 1.3 & 86.5 & $500^{\circ} \mathrm{C}$ in $\mathrm{N}_{2}$ & 26 \\
\hline $\begin{array}{l}\text { Carbonized upper } \\
\text { leaves of rice straw }\end{array}$ & 1.2 & 75.8 & $\begin{array}{l}\text { Different temperature } \\
\left(350^{\circ} \mathrm{C} \text { and } 500^{\circ} \mathrm{C}\right)\end{array}$ & 27 \\
\hline $\begin{array}{l}\text { Carbonized } \\
\text { Enteromorpha prolifera }\end{array}$ & $1.1-1.3$ & $80-84$ & $600^{\circ} \mathrm{C}$ for 2 hours & 28 \\
\hline $\begin{array}{l}\text { Carbonized platanus } \\
\text { fruit }\end{array}$ & 2 & 81.3 & $\begin{array}{l}180^{\circ} \mathrm{C} \text { for } 1 \text { hour and } \\
\text { further } 600^{\circ} \mathrm{C} \text { for } 1 \\
\text { hour }\end{array}$ & 29 \\
\hline Carbonized bamboos & 1.547 & 62.3 & $\begin{array}{l}\text { air dried at } 100^{\circ} \mathrm{C} \text { for } \\
12 \mathrm{~h} \text { then carbonized } \\
\text { at } 350^{\circ} \mathrm{C} \text { for } 60 \mathrm{~min} \text {, } \\
\text { further carbonized at } \\
500^{\circ} \mathrm{C} \text { for } 40 \text { min and } \\
\text { at the end, calcination } \\
\text { at } 900^{\circ} \mathrm{C} \text { for } 240 \text { min. }\end{array}$ & 30 \\
\hline Carbonized tissue & $\geq 1$ & 64 & $\begin{array}{l}\text { Calcination in } 800^{\circ} \mathrm{C} \\
\text { in argon }\end{array}$ & 31 \\
\hline $\begin{array}{l}\text { Dry Toner Coated Egg } \\
\text { tray } \\
\text { CET rough texture } \\
\text { CET smooth texture }\end{array}$ & $\begin{array}{l}1.3 \\
1.201\end{array}$ & $\begin{array}{l}78.5 \\
72.7\end{array}$ & $\begin{array}{l}\text { Heat treatment at } 95 \\
{ }^{\circ} \mathrm{C} \text { for } 1 \text { hour inside } \\
\text { drying oven. }\end{array}$ & $\begin{array}{l}\text { This } \\
\text { Work }\end{array}$ \\
\hline
\end{tabular}




\section{Supporting Note 7:}

\section{Cost Analysis}

Table ST3: Cost approximation for generating 0.5 litre purified water per day using the proposed solar evaporator.

\begin{tabular}{|c|c|c|c|c|}
\hline $\begin{array}{l}\text { SI. } \\
\text { No }\end{array}$ & Item & $\begin{array}{l}\text { Cost per unit } \\
\text { (USD) }\end{array}$ & Quantity & $\begin{array}{l}\text { Total Cost } \\
\text { (USD) }\end{array}$ \\
\hline \multicolumn{5}{|c|}{ Solar Absorber } \\
\hline 1. & Egg tray & $\begin{array}{c}\$ 0.5 \text { per } 0.0625 \\
\mathrm{~m}^{2}\end{array}$ & 1 & $\$ 0.5$ \\
\hline 2. & $\begin{array}{l}\text { Dry toner (collected } \\
\text { from waste toner } \\
\text { drum) }\end{array}$ & $\begin{array}{l}\$ 0.95 \text { per } 10 \\
\text { grams }\end{array}$ & 6 grams & $\$ 0.57$ \\
\hline 3. & Polyurethane foam & $\begin{array}{l}\$ 2.3 \text { per sq. } \\
\text { meter }\end{array}$ & $\begin{array}{l}0.0625 \mathrm{sq} . \\
\text { meter }\end{array}$ & $\$ 0.14$ \\
\hline 4. & Isopropanol & $\begin{array}{c}\$ 2.56 \text { per } 1000 \\
\mathrm{ml}\end{array}$ & $240 \mathrm{ml}$ & $\$ 0.61$ \\
\hline 5. & Miscellaneous & - & - & $\$ 1$ \\
\hline \multicolumn{5}{|c|}{ Glass Box for Collecting Evaporated Water } \\
\hline 6. & $\begin{array}{l}\text { Glass }(100 \mathrm{~cm} \times 30 \\
\mathrm{cm} \times 2 \mathrm{~cm})\end{array}$ & $\$ 2.14$ & 1 & $\$ 2.14$ \\
\hline 7. & Glue and others & - & - & $\$ 2.8$ \\
\hline \multicolumn{4}{|c|}{$\begin{array}{c}\text { Total cost (USD) [cost of solar absorber }(\$ 2.82)+\text { cost of box } \\
(\$ 4.94)]\end{array}$} & $\$ 7.76$ \\
\hline
\end{tabular}

Average evaporated water condensed by day using the manufactured box is 0.5 litre. Considering that out of 365 days in a year, 65 days will be rainy days or cloudy days in a tropical region, the average annual water production will be 150 litres. Assuming the lifetime of the glass box of 2 years with a replacement and maintenance cost of $\$ 2$ per year and the bi-monthly replacement period of the solar absorber, the cost of water purification can be calculated as follows.

Annual water production $=150$ litres

Annual cost for the solar absorber $=\$ 16.92$

Annual cost for the collection box with replacement \& maintenance cost $=\$ 6.94$

Total cost for generating 150 litres of water in a year $=\$ 23.86$ 
Cost per litre of purified water $=\$ 0.16$

The cost of per litre of purified water using the proposed system is $\$ 0.16$ whereas in the US market, the average cost of 1 litre of bottled water in December 2021 is $\$ 0.31$ which is almost 2 times higher than the cost of purified water produced by the proposed system.

\section{Reference}

(1) Su, Y.; Wu, Y.; Liu, M.; Qing, Y.; Zhou, J.; Wu, Y. Ferric lons Modified Polyvinyl Alcohol for Enhanced Molecular Structure and Mechanical Performance. Materials (Basel). 2020, 13 (6), 1-13. https://doi.org/10.3390/ma13061412.

(2) Kachel-Jakubowska, M.; Matwijczuk, A.; Gagoś, M. Analysis of the Physicochemical Properties of Post-Manufacturing Waste Derived from Production of Methyl Esters from Rapeseed Oil. Int. Agrophysics 2017, 31 (2), 175-182. https://doi.org/10.1515/intag-2016-0042.

(3) San-Blas, E.; Guerra, M.; Portillo, E.; Esteves, I.; Cubillán, N.; Alvarado, Y. ATR/FTIR Characterization of Steinernema Glaseri and Heterorhabditis Indica. Vib. Spectrosc. 2011, 57 (2), 220-228. https://doi.org/10.1016/j.vibspec.2011.07.008.

(4) Chen, Y.; Zou, C.; Mastalerz, M.; Hu, S.; Gasaway, C.; Tao, X. Applications of MicroFourier Transform Infrared Spectroscopy (FTIR) in the Geological Sciences-A Review. Int. J. Mol. Sci. 2015, 16 (12), 30223-30250.

https://doi.org/10.3390/ijms161226227.

(5) Malenab, R. A. J.; Ngo, J. P. S.; Promentilla, M. A. B. Chemical Treatment of Waste Abaca for Natural Fiber-Reinforced Geopolymer Composite. Materials (Basel). 2017, 10 (6). https://doi.org/10.3390/ma10060579.

(6) Kharazmi, A.; Faraji, N.; Hussin, R. M.; Saion, E.; Yunus, W. M. M.; Behzad, K. Structural, Optical, Opto-Thermal and Thermal Properties of ZnS-PVA Nanofluids Synthesized through a Radiolytic Approach. Beilstein J. Nanotechnol. 2015, 6 (1), 529-536. https://doi.org/10.3762/bjnano.6.55.

(7) Liu, X.; Liu, Z.; Wang, L.; Zhang, S.; Zhang, H. Preparation and Performance of Composite Films Based on 2-(2-Aminoethoxy) Ethyl Chitosan and Cellulose. RSC Adv. 2017, 7 (23), 13707-13713. https://doi.org/10.1039/c6ra26541c. 
(8) Zhuang, J.; Li, M.; Pu, Y.; Ragauskas, A. J.; Yoo, C. G. Observation of Potential Contaminants in Processed Biomass Using Fourier Transform Infrared Spectroscopy. Appl. Sci. 2020, 10 (12), 1-13. https://doi.org/10.3390/app10124345.

(9) Farid, S.; Kasem, M. A.; Zedan, A. F.; Mohamed, G. G.; El-Hussein, A. Exploring ATR Fourier Transform IR Spectroscopy with Chemometric Analysis and Laser Scanning Microscopy in the Investigation of Forensic Documents Fraud. Opt. Laser Technol. 2021, 135, 106704. https://doi.org/10.1016/j.optlastec.2020.106704.

(10) Trivedi, M. K.; Tallapragada, R. M.; Branton, A.; Trivedi, D.; Nayak, G.; Latiyal, O. Characterization of Physical and Structural Properties of Aluminium Carbide Powder: Impact of Biofield Treatment Aeronautics \& Aerospace Engineering Characterization of Physical and Structural Properties of Aluminium Carbide Powder : Impact of Biofield T. 2015, No. August. https://doi.org/10.4172/2168-9792.1000142.

(11) Nguyen, Q. H.; Quyen, D. H.; Hoang, T. K. N. A New Route of Emulsifier-Free Emulsion Polymerization for the Preparation of Polymer Coated Magnetite Nanoparticles. Mater. Sci. 2014, 32 (2), 264-271. https://doi.org/10.2478/s13536-0130172-y.

(12) Hodúr, C.; Bellahsen, N.; Mikó, E.; Nagypál, V.; Šereš, Z.; Kertész, S. The Adsorption of Ammonium Nitrogen from Milking Parlor Wastewater Using Pomegranate Peel Powder for Sustainable Water, Resources, and Waste Management. Sustain. 2020, 12 (12). https://doi.org/10.3390/SU12124880.

(13) Tapera, M.; Wanjau, R.; Machocho, A. K.; Mutsiba, P. P.; Kaseke, S. Phytochemical Profile of Plecranthusesculentus N. E . Br Obtained from Zimbabwe Authenticates Its Medicinal Uses Phytochemical Profile of Plecranthusesculentus N . E . Br Obtained from Zimbabwe Authenticates Its Medicinal Uses Abstract : 2020, No. September. https://doi.org/10.9790/5736-1309013441.

(14) Zięba-palus, J. The Usefulness of Infrared Spectroscopy in Examinations of Adhesive Tapes for Forensic Purposes. 2017, 2 (2), 1-9.

https://doi.org/10.15761/FSC.1000112.

(15) Zhang, Y.; Ye, M.; Han, A.; Ding, C.; Yang, J.; Zhang, K. Preparation and Characterization of Encapsulated CoAl2O4 Pigment and Charge Control Agent for Ceramic Toner via Suspension Polymerization. Ceram. Int. 2018, 44 (16), 2032220329. https://doi.org/10.1016/j.ceramint.2018.08.020.

(16) Ciocia, C.; Marinetti, S. In-Situ Emissivity Measurement of Construction Materials. 
2012, No. November. https://doi.org/10.21611/qirt.2012.168.

(17) Hu, M.; Yu, D.; Wei, J. Thermal Conductivity Determination of Small Polymer Samples by Differential Scanning Calorimetry. Polym. Test. 2007, 26 (3), 333-337. https://doi.org/10.1016/j.polymertesting.2006.11.003.

(18) Ramires, M. L. V.; Nieto Castro, C. A.; Nagasaka, Y.; Nagashima, A.; Assael, M. J.; Wakeham, W. A. Standard Reference Data for the Thermal Conductivity of Water. J. Phys. Chem. Ref. Data 1995, 24 (3), 1377-1381. https://doi.org/10.1063/1.555963.

(19) Muthuraj, R.; Jimenez-Saelices, C.; Grohens, Y.; Seantier, B. Applications of Polysaccharide and Protein Based Aerogels in Thermal Insulation; 2018; Vol. 2018Janua. https://doi.org/10.1039/9781782629979-00261.

(20) Xu, N.; Hu, X.; Xu, W.; Li, X.; Zhou, L.; Zhu, S.; Zhu, J. Mushrooms as Efficient Solar Steam-Generation Devices. Adv. Mater. 2017, 29 (28), 1-5.

https://doi.org/10.1002/adma.201606762.

(21) Wang, C. F.; Wu, C. L.; Kuo, S. W.; Hung, W. S.; Lee, K. J. Preparation of Efficient Photothermal Materials from Waste Coffee Grounds for Solar Evaporation and Water Purification. Sci. Rep. 2020, No. 0123456789, 1-10. https://doi.org/10.1038/s41598020-69778-2.

(22) Zhang, Y.; Ravi, S. K.; Vaghasiya, J. V.; Tan, S. C. A Barbeque-Analog Route to Carbonize Moldy Bread for Efficient Steam Generation. iScience 2018, 3, 31-39. https://doi.org/10.1016/j.isci.2018.04.003.

(23) Liu, C.; Hong, K.; Sun, X.; Natan, A.; Luan, P.; Yang, Y.; Zhu, H. An "antifouling" Porous Loofah Sponge with Internal Microchannels as Solar Absorbers and Water Pumpers for Thermal Desalination. J. Mater. Chem. A 2020, 8 (25), 12323-12333. https://doi.org/10.1039/d0ta03872e.

(24) Lu, Y.; Wang, X.; Fan, D.; Yang, H.; Xu, H.; Min, H.; Yang, X. Biomass Derived Janus Solar Evaporator for Synergic Water Evaporation and Puri Fi Cation. 2020, 25. https://doi.org/10.1016/j.susmat.2020.e00180.

(25) Lu, Y.; Dai, T.; Fan, D.; Min, H.; Ding, S.; Yang, X. Turning Trash into Treasure: Pencil Waste-Derived Materials for Solar-Powered Water Evaporation. Energy Technol. 2020, 8 (10), 1-9. https://doi.org/10.1002/ente.202000567.

(26) Fang, J.; Liu, J.; Gu, J.; Liu, Q.; Zhang, W.; Su, H.; Zhang, D. Hierarchical Porous Carbonized Lotus Seedpods for Highly Efficient Solar Steam Generation. Chem. 
Mater. 2018, 30 (18), 6217-6221. https://doi.org/10.1021/acs.chemmater.8b01702.

(27) Fang, Q.; Li, T.; Chen, Z.; Lin, H.; Wang, P.; Liu, F. Full Biomass-Derived Solar Stills for Robust and Stable Evaporation To Collect Clean Water from Various WaterBearing Media. 2019. https://doi.org/10.1021/acsami.9b00291.

(28) Yang, L.; Chen, G.; Zhang, N.; Xu, Y.; Xu, X. Sustainable Biochar-Based Solar Absorbers for High-Performance Solar-Driven Steam Generation and Water Puri Fi Cation. 2019. https://doi.org/10.1021/acssuschemeng.9b06169.

(29) Yuan, B.; Zhang, C.; Liang, Y.; Yang, L.; Yang, H.; Bai, L.; Wei, D.; Wang, W.; Wang, Q.; Chen, H. A Low-Cost 3D Spherical Evaporator with Unique Surface Topology and Inner Structure for Solar Water Evaporation-Assisted Dye Wastewater Treatment. Adv. Sustain. Syst. 2021, 5 (3), 2000245. https://doi.org/10.1002/adsu.202000245.

(30) Bian, Y.; Du, Q.; Tang, K.; Shen, Y.; Hao, L.; Zhou, D.; Wang, X.; Xu, Z.; Zhang, H.; Zhao, L.; Zhu, S.; Ye, J.; Lu, H.; Yang, Y.; Zhang, R.; Zheng, Y.; Gu, S. Carbonized Bamboos as Excellent 3D Solar Vapor-Generation Devices. Adv. Mater. Technol. 2019, 4 (4), 1-7. https://doi.org/10.1002/admt.201800593.

(31) Chen, Y.; Shi, Y.; Kou, H.; Liu, D.; Huang, Y.; Chen, Z.; Zhang, B. Self-Floating Carbonized Tissue Membrane Derived from Commercial Facial Tissue for Highly Efficient Solar Steam Generation. ACS Sustain. Chem. Eng. 2019, 7 (3), 2911-2915. https://doi.org/10.1021/acssuschemeng.8b05830. 